\title{
The Function and Meaning of Hand-Lettering at Cafes in Padang
}

\author{
Hendra Afriwan, Dini Faisal, and San Ahdi \\ Program Studi Desain Komunikasi Visual \\ Universitas Negeri Padang \\ Padang, Indonesia \\ dinifaisal09@gmail.com
}

\begin{abstract}
Nowadays, trend in almost every café in Padang, West Sumatra, Indonesia, use hand lettering in their café interior. This phenomenon spreads from one café to another, whether it is a full hand-lettering interior or a low scale hand-lettering interior. This paper describes those hand-lettering functions and meanings in correlation with café's concept and its costumer. Research methodology for this study is qualitative descriptive with observation and documentation methods. Findings indicate that 1) there are three functions in handlettering such as to identify, to inform, and to create emotion; 2) hand-letterings only found in cafes under good governance management.
\end{abstract}

Keywords-function, meaning, hand-lettering, café

\section{INTRODUCTION}

Padang - a state province in West Sumatra, Indonesia — has started to follow trends from bigger cities in Indonesia. One of the trends is the emergence of cafes in Padang in the last two years. Most of the cafes nowadays offers places to hang out, not only places to eat. They sell emotional experiences in addition to beverages. The experiences they offer can be seen in the cafes interior design such as using illustrations and letterings to attract costumers. This lettering design especially hand-lettering is wide-spread and can be found in most of newly opened cafes whether it is part of cafes concept or just an addition to entice costumers.

The definition of lettering is drawing letterforms (Sy, 2016). Hand-lettering is drawing letterforms through any medium manually by hand. In other words, lettering is a process of designing letterforms into sentences as part of visual messages. There are two keywords in lettering which are creative letterforms and visual message. Visual message is a form of communication in conveying information from sender (in this case lettering artist or designer) to receiver (costumers) so there is an exchange of meaning and understanding. Apart of what the message is lettering designer should pay attention to how the letters displayed visually. According to Heller and Ilic (2012) information can be presented in a straightforward manner or in a demonstrative typographic that draws attention. Furthermore "Type and image, composition and arrangement, color and hue-choices that designers make all the time - can make a huge difference in how we receive the messages and, ultimately, take those persistent orders from others".

Lettering is commonly used in visual communication design, manually or digitally. The basic functions of visual communication design according to Anggraini and Nathalia (2014) are: 1) to identify (branding process), 2) to inform, 3) as motivational tools, 4) emotional means, 5) presentation and promotion tools. Meanwhile, according to Heller and Ilic (2012), typography and graphic design can be use as a tool to raise awareness or even influence people's behavior. There are eight principles of how typography and graphic design affect people: inform, advocate, play, caution, entertain, express, educate, transform. This paper focuses on analyzing the functions and meanings of hand lettering found at cafes in Padang.

\section{METHOD}

This paper used qualitative descriptive as research methodology. Qualitative research intends to understand the phenomena that occur by way of description in the form of words and language, in a special context that is natural by utilizing various natural methods. This research is to interpret and explain the facts that exist in hand-lettering at cafes in Padang. Data collected through observation in five cafes as sample. Samples were taken from two kecamatan or districts, which are West Padang and East Padang, two districts with growing entertainment and shopping centers.

\section{FINDINGS AND DISCUSSION}

This paper discussed about the function and meaning of hand-lettering used in cafes interior. Samples were taken from Cobek Penyet Café, Kiosk Signature café, Karambia café, The Kafe café and Panties Pizza café. The first four were from West Padang district and the last one from East Padang. Café is a type of restaurant that offers variety of snacks such as cakes, breads and soups. For drinks they usually served tea, coffee and chocolate. Observation indicates that hand lettering in cafes have three functions, such as 1) to identify, 2) to inform, and 3) to entertain using emotional means. 
The main function of visual communication design, in this case hand-lettering, is as a means of identification. "In a world dominated by the visual, businesses and organizations have to be able to offer a sign, a symbol—a house style — that identifies them" (Shaughnessy, 2010). According to Anggraini and Nathalia (2014) the means of identification is a form of recognition of a person's, company's, product's, or service's identity. Logo is the main form of visual identification.

Findings indicate that some cafes implement its logo using hand-lettering on the interior wall of the café, such as Panties Pizza and Cobek Penyet. These hand-lettering were used as an additional tools other than the main identity located on the café exterior. The purpose of this secondary logo is to remind costumers of the café logo as a part of branding. As Laseau (2001) suggest, "Basic communication theory stresses the communication loop between the communicator or sender and the receiver in order to attain maximum effectiveness". So, this kind of repetition meant to create maximum memory for costumers. This hand lettering identity were made permanently because generally logo is long lasting. Through observation researcher found that all of the handlettering identity made on a brick-exposed wall like figures below.

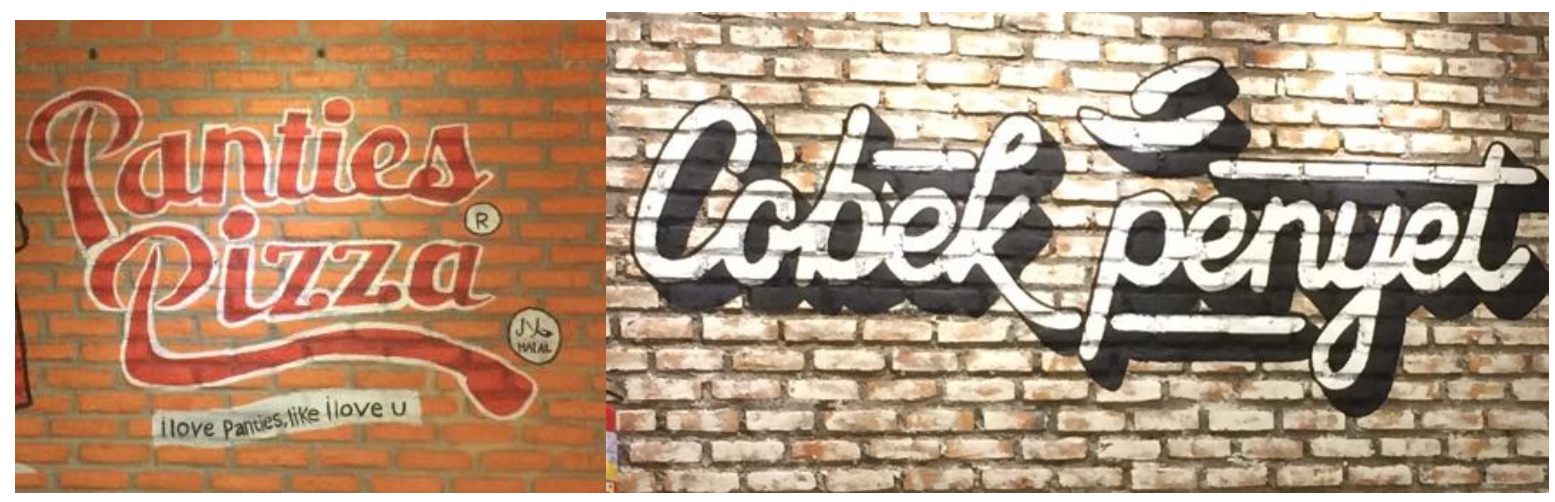

Fig 1. Hand-lettering with identity function

The next function of hand-lettering in cafes is to inform people. To inform means to provide instructions, messages or directions. Findings indicate that most cafés use this function to inform costumers of toilet directions, floor directions, café menus and operational hours. According to Anggraini and Nathalia (2014) the purpose of this function is to show a correlation between objects. Information can only work if using the right media to inform the right messages to the right audiences. Meanwhile, Heller and Ilic (2012) stated that "informing is the job of graphic design. Causing the receiver to act or alter behavior based on that information is the goal". Informing is quite tricky because hand lettering needs to be artistically beautiful while providing clarity. Furthermore, Heller and Ilic (2012) describes "informing is tricky insofar as it is important not to overpower the information with conceptual cleverness or typographic conceit". For example, hand-lettering menu should be easily read while the layout and the letter forms should be aesthetic.

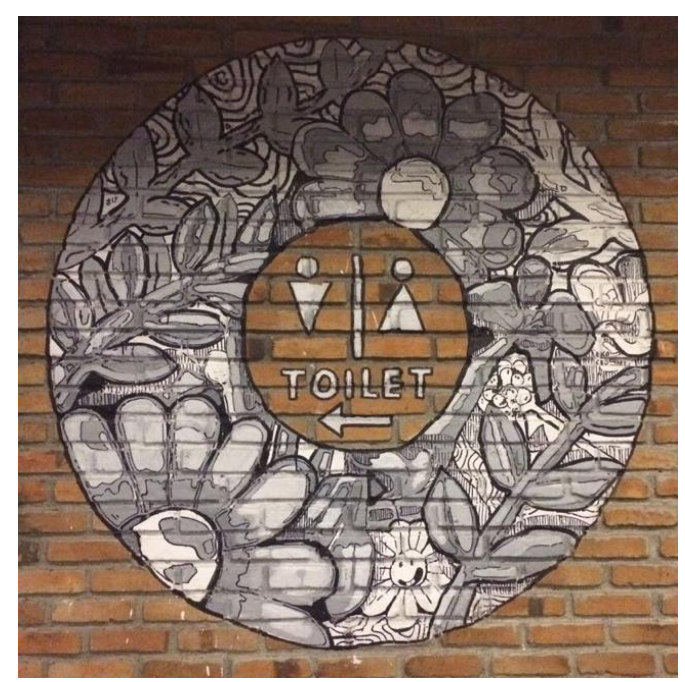

Fig. 2 Permanent informational hand lettering

Based on observation, researcher found that there are two characteristics of media used in hand-lettering due to different needs of information. The characteristics are permanent and non-permanent. Permanent information use permanent media such as walls 
and permanent ink while non-permanent information use non-permanent media such as chalkboards and chalks. The categories of permanent information are toilet directions and floor directions since that kind of information is usually everlasting. Most cafes will not change much after it's first open. It's reasonable to apply such information on long lasting media.

Café menus and operational hours categorized as non-permanent information. This kind of information applied on nonpermanent media such as chalkboards using colorful chalks. Some were found as hanging chalkboards and some were standing chalkboards. Practicality is one of the reasons why cafes use chalkboards. Some cafés use different menu each week such as "bestseller menu" or "menu of the week". Therefore, it's easier to change this menu in a non-permanent media. Based on observation, researcher found that all non-permanent information on non-permanent media use simple hand lettering and even just a handwriting. It is believed that this lettering designed by the café's employee without using hand lettering artists. We conclude that lettering artists in Padang isn't as popular as in Jakarta - capital city of Indonesia were most cafes hire lettering artists to decorate their café in permanent and non-permanent media.

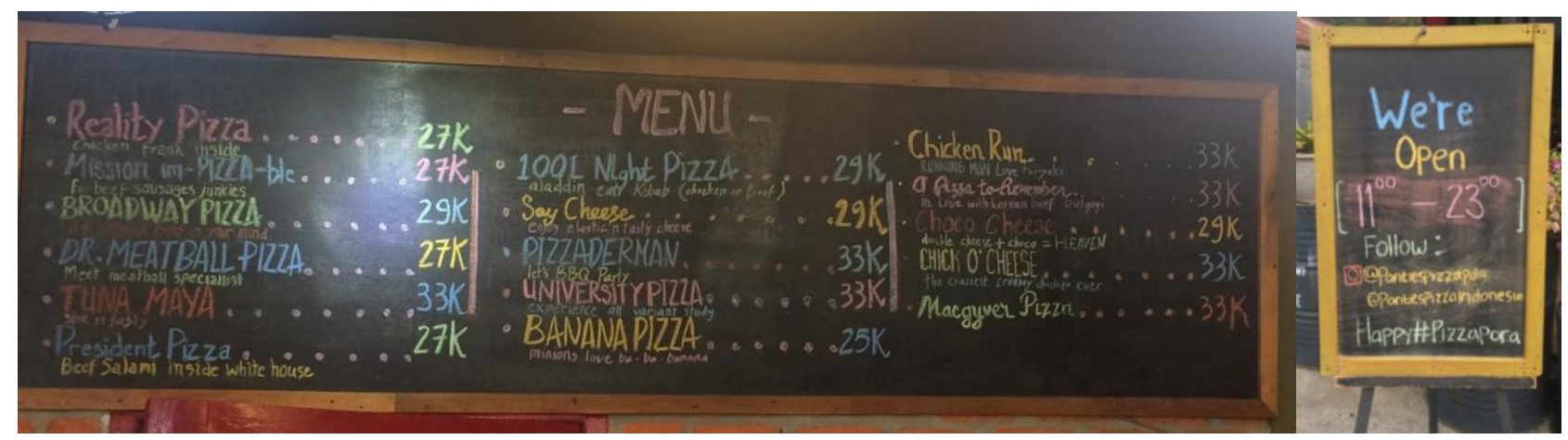

Fig. 3 Non-permanent informational hand lettering

The last function of hand-lettering in cafes is to entertain using emotional expressions. According to Anggraini and Nathalia (2014) "communication using emotional expressions used to create ambience in order to increase sensitivity to the reader". This function commonly used at cafes in Padang. Almost all cafes have this kind of lettering functions. This kind of lettering used to create dining atmosphere in the cafes. Based on the data, researcher found that there are two types of entertain function. First, letterings with writings or messages directly matched cafes' identity and second, messages which are not.

Lettering with messages directly matched cafes' identity is uncommon. This can only be found at Panties Pizza, as the name suggest this café sells pizza. This café is one of the café which has various hand letterings on each wall inside the café. All of the letterings contains messages associated with pizza. Such as, "you can't buy happiness but you can buy pizza" and "I like someone to look at me like I look at pizza". These persuasive messages emphasize café's identity and create an ambience where costumers steadily reminded about pizza in a fun, entertaining way.

Common entertain function found in cafes are using the second type which is letterings with no direct messages to cafes' identity. For examples on figure below, a lettering of "makan"- translated to "eat"- and its humorous explanation. This lettering has no direct relation to its café identity Cobek Penyet which serve traditional beverages. Lettering "eat" could be associated with any café and not only Cobek Penyet. This lettering is more general and has no personal relation to cafés identity or concept. Another example is at The Kafe with lettering about "music is what feeling sound like" which is not related to the cafe's identity. This kind of lettering is made to create ambiance with messages about anything general which can attract costumers mind but could not be associated with each of the cafes' identity. However, it doesn't make it less entertaining since it can also create good dining experience with motivational, emotional expressions through lettering messages.

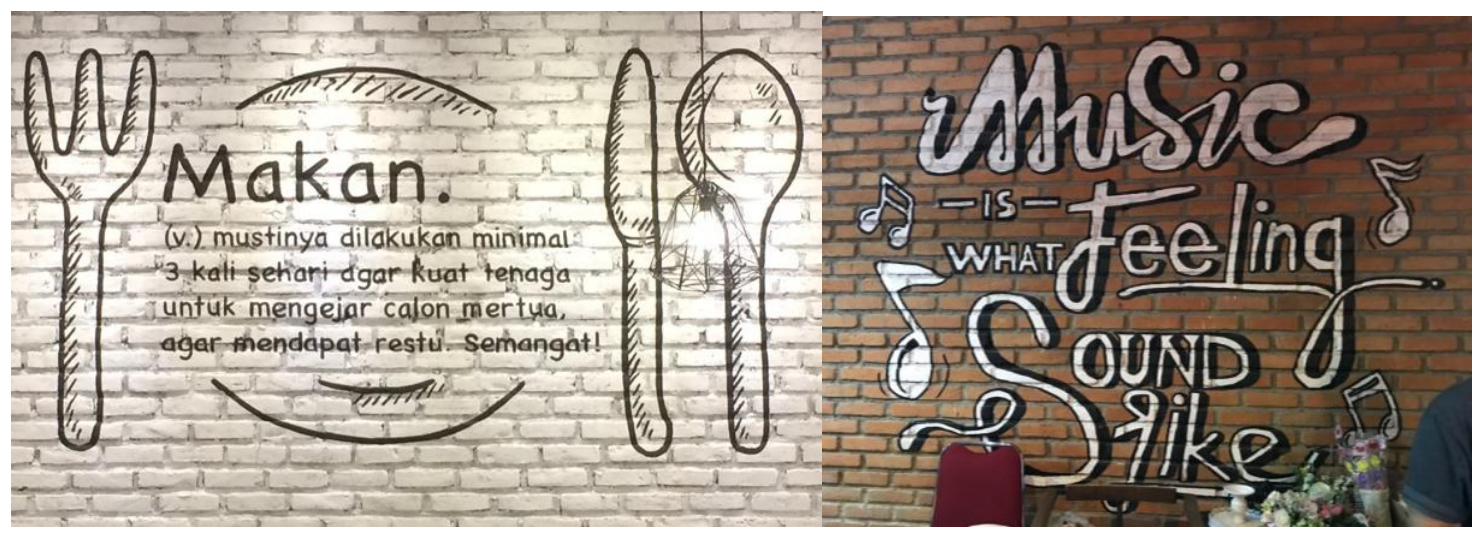


Fig. 4 hand letterings to entertain

In addition to two types of entertainment function, there is a thematic lettering such as the one found at Karambia café. The theme is "Idhul Adha" - a special religious event for Muslims community. Since this is a thematic type it can only be found on chalkboards using colorful chalks.

Aside from analyzing hand-lettering functions, this paper also describes about lettering meaning using semiotic approach by Charles Sanders Pierce. The theory refers to Pierce's semiotic approach are: the study of signs using icon, index and symbol. Tinarbuko (2008), states that symbols are signs based on mutually agreed conventions, rules and agreements. The new symbol can be understood if someone already understands the meaning that has been agreed previously.

Signs in human life can be visual signs or gestures. A hand wave or a nod can be translated into agreement. The example of sound signs such as trumpet blowing, drums, human voice, telephone ringing and so on. Writing signs such as letters and numbers. Visual signs such as traffic signs, illustrations and so on.

Pierce's theory using icon, index and symbol. Signs that we see, hear, or read have meaning. What is expressed through the sign called as reference. Based on the relationship between sign and reference, Pierce divides the three relationships as follows:

1. The relationship of similarity between sign and the reference, called Icon

2. The relationship that arises because there is proximity of its existence, called index

3. Relationships that are conventionally formed, called symbols

This paper analyzes three different lettering and describe their meanings using Pierce semiotic theory. First lettering is from Karambia café, the figure is in Table 1 below. On the left column of the table is a lettering completed with icons of fork and knife. The letters "Bon Appetite" itself drawn above a circle represent a plate. There is a circular line as decoration bellow the letterforms. The lettering style is called "miscellaneous" which is a style derives from previous letterform. Overall, the lettering style is seen as decorative and ornamental. The table below describes both signifier and signified based on Saussure's theory.

\begin{tabular}{|c|c|c|}
\hline Lettering & signifier & signified \\
\hline & fork & stability \\
\hline & plate & flexibility \\
\hline & knife & convenience \\
\hline & Circular line & birth \\
\hline
\end{tabular}

In this semiotic discussion, lettering "Bon Appetite" indicates a satisfactory meaning. Furthermore, it states about satisfaction in services, comfortably huge space, a satisfied costumer, and a growing business. It is a positive meaning, which works both way to café's costumers and its business owner.

The second lettering to be analyzed is an information of café's menu from Kiosk Signature. This lettering is a non-permanent lettering on a chalkboard. Below is the explanation of its signifier and signified on Table II.

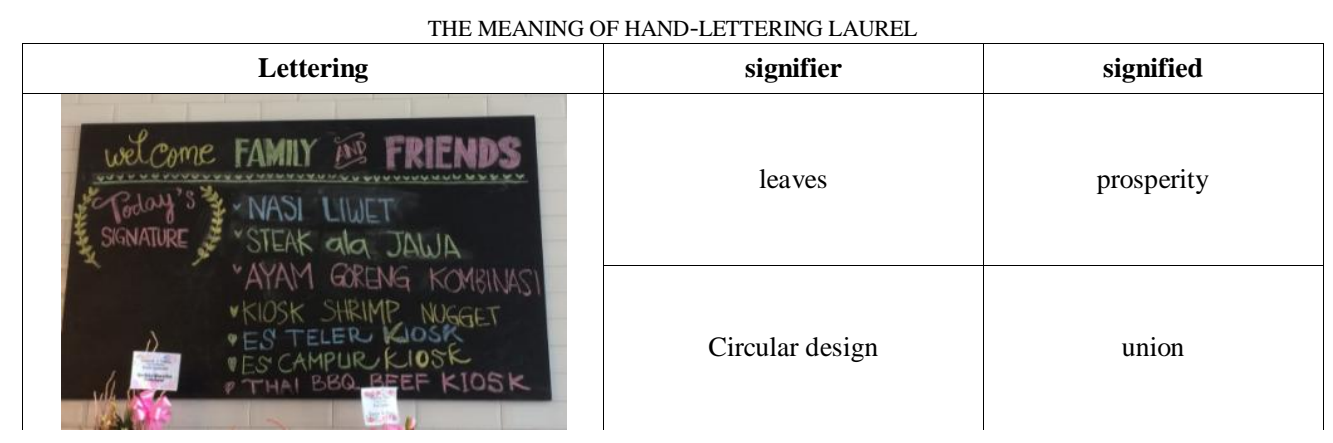

The figure above on table II is an information board about today's signature dish. It consists of a rendition of laurel wreath and a writing of "today's signature". Laurel wreath is a symbol of victory and honor. It was used in Greek mythology. In this lettering it is meant as a token of appreciation and respect to customer.

The last sign to be analyzed is a hand-lettering found at The Kafe. It is an information sign made permanent on cafe's interior wall. This lettering is a mix of letters (writing), icons, and illustration. The explanation of its signifier and signified listed in the table III below. 


\begin{tabular}{|l|c|c|} 
THE MEANING OF HAND-LETTERING INFORMATION SIGN \\
\hline \multirow{2}{*}{ lettering } & signifier & signified \\
\hline \multirow{2}{*}{} & Male icon & strength \\
\hline & Female icon & tenderness \\
\hline & circle & Focus \\
\hline & fertility \\
\hline
\end{tabular}

The sign above can be interpreted as nature and harmony. The arrow signed place or location. It may be uncommon to associate a restroom with something as nature, coolness, tenderness. But here it signifies that the café offers a cleaned and wellmanaged restroom. It is a statement from the café that they take a good care of their place.

\section{CONCLUSION AND RECOMMENDATION}

From discussion above, we conclude that hand-lettering can be analyzed by its functions and meanings. There are three functions of hand-lettering, such as: 1) to identify, 2) to inform, 3) to entertain. While hand-lettering meaning depends on the signs and its signifier.

Hand-lettering has permanent and non-permanent properties, depends on what was needed. For example, a permanent handlettering used for identity because identity is long lasting. It is also used for information that will not change regularly such as toilet and floor directions. As for non-permanent hand-lettering is usually used for information that change regularly such as menus, operational hours and a thematic information.

A permanent hand lettering commonly found on cafes' wall whereas non-permanent hand-lettering use chalkboard. Selection of this media depends on the lettering necessity. For example, the use of chalkboard is easier for new information that changed periodically. The next research could be about categorizing hand-lettering style, which style commonly found and which style are not.

\section{References}

Anggraini, S. L and Nathalia, K. (2014). Desain komunikasi visual: dasar-dasar panduan untuk pemula. Bandung: Nuansa Cendikia Heller, S and Ilic, M. (2012). Stop think go do: how typography and graphic design influence behavior. Massachusetts: Rockport Publishers Laseau, P. (2001). Graphic thinking for architects and designers. New York: John Wiley and Sons, Inc.

Shaughnessy, A. (2010). How to be a graphic designer, without losing your soul. New York: Princeton Architectural Press.

Sy, A. (2016). The abcs of hand lettering. Jakarta: Haru Publisher

Tinarbuko, S. (2008). Semiotika komunikasi visual. Yogyakarta: Jalasutra 